\title{
Potensi Ekstrak Etanol Buah Citrullus lanatus sebagai Agen Imunosupresi melalui Pengamatan Histologi Limpa Mencit BALB/c
}

\author{
Sri Nabawiyati Nurul Makiyah, ${ }^{1}$ Ulinna`ma Hayati Wardhani ${ }^{2}$ \\ ${ }^{1}$ Bagian Histologi Fakultas Kedokteran dan Ilmu KesehatanmUniversitas Muhammadiyah Yogyakarta \\ ${ }^{2}$ Program Studi Pendidikan Dokter Universitas Muhammadiyah Yogyakarta
}

\begin{abstract}
Citrullus lanatus mengandung flavonoid yang berpotensi sebagai agen imunosupresi. Penelitian ini bertujuan mengkaji perubahan diameter pulpa alba limpa mencit BALB/c yang diinduksi ovalbumin (OVA) setelah pemberian ekstrak etanol buah C. lanatus. Jenis penelitian ini adalah eksperimental dengan post-test only control group design. Sebanyak 30 ekor mencit BALB/c jantan dibagi menjadi enam kelompok, yaitu tiga kelompok kontrol (normal, negatif, dan metilprednisolon) dan tiga kelompok perlakuan ekstrak etanol C. lanatus dosis 175 $\mathrm{mg} / \mathrm{kgBB}, 350 \mathrm{mg} / \mathrm{kgBB}$, dan $700 \mathrm{mg} / \mathrm{kgBB}$ per hari. Ekstrak dan Metilprednisolon diberikan selama 28 hari, sedangkan OVA diberikan pada hari ke-15 dan ke-22 secara intraperitoneal dan per oral pada hari ke-23 sampai dengan hari ke-28. Pada hari ke-29, mencit dikorbankan dan organ limpa diambil untuk dibuat sediaan histologi dengan teknik pewarnaan HE. Efek imunosupresi dinilai dari rata-rata diameter pulpa alba limpa. Data dianalisis dengan uji nonparametrik Kruskal-Wallis dilanjutkan uji Mann-Whitney. Diameter pulpa alba limpa mengalami peningkatan setelah diinduksi OVA, pemberian ekstrak etanol C. lanatus dosis $700 \mathrm{mg} / \mathrm{kgBB}$ dan metilprednisolon menyebabkan penurunan diameter pulpa alba limpa secara bermakna $(\mathrm{p}<0,05)$, tetapi ekstrak etanol $C$. lanatus dosis 175 dan $350 \mathrm{mg} / \mathrm{kgBB}$ tidak menurunkan diameter pulpa alba limpa. Ekstrak etanol C. lanatus dosis 700 $\mathrm{mg} / \mathrm{kgBB}$ mampu menurunkan diameter pulpa alba pada limpa mencit BALB/c yang diinduksi OVA sehingga berpotensi sebagai agen imunosupresi. [MKB. 2017;49(4):245-51]
\end{abstract}

Kata kunci: Agen imunosupresi, citrullus lanatus, mencit BALB/c, ovalbumin, pulpa alba limpa

\section{Citrullus lanatus Ethanol Extract Potential as Immunosupressive Agent based on Spleen Histology Observation in BALB/c Mice}

\begin{abstract}
Citrullus lanatus contains flavonoid which is known as an immunosuppresion agent. This study aimed to evaluate $\mathrm{BALB} / \mathrm{c}$ mice spleen white pulp diameter after Ovalbumin (OVA) induction and administration of C. lanatus ethanol extract. This was a post-test only control group experimental study. Thirty male BALB/c mice were divided into six groups consisting of three control groups (normal, negative, and methylprednisolone) and three C. lanatus ethanol extract treatment groups ( $175 \mathrm{mg} / \mathrm{kg} \mathrm{bw}, 350 \mathrm{mg} / \mathrm{kg} \mathrm{bw}$, and $700 \mathrm{mg} / \mathrm{kg}$ bw dose per day). The ethanol extract and methylprednisolone were administered to the respective groups for 28 consecutive days, while the OVA was given intraperitoneally on day 15 and day 22 and orally from day 23 to day 28. On day 29, the mice were sacrificed and their spleen were processed histologically using the HE staining technique. The immunosupression effect was assessed by measuring the white pulp spleen diameter. Data were analyzed using nonparametric Kruskal-Wallis test, followed by Mann-Whitney test. After OVA induction, the diameter of white pulp spleen was found to increase. Significant decrease in the spleen white pulp diameter $(\mathrm{p}<0.05)$ was seen in the $700 \mathrm{mg} / \mathrm{kgbw} \mathrm{C}$. lanatus ethanol extract group and methylprednisolone group. No shortening of the spleen white pulp diameter was seen in $175 \mathrm{mg} / \mathrm{kg}$ bw and $350 \mathrm{mg} / \mathrm{kgbw} \mathrm{C}$. lanatus ethanol extract groups. Hence, 700 $\mathrm{mg} / \mathrm{kgbw} \mathrm{C}$. lanatus ethanol extract can decrease the spleen white pulp diameter in an OVA-induced BALB/c mice and may have a potential to be used as an immunosuppressive agent. [MKB. 2017;49(4):245-51]
\end{abstract}

Key words: BALB/c mice, citrullus lanatus, immunosuppresion agent, ovalbumin, white pulp of spleen

Korespondensi: Dr. Sri Nabawiyati Nurul Makiyah, S. Si., M. Kes, Bagian Histologi Fakultas Kedokteran dan Ilmu Kesehatan Universitas Muhammadiyah Yogyakarta,Jl.LingkarSelatan, Kasihan Bantul, Yogyakarta55183,E-mail:nurul_makiyah@umy.ac.id 


\section{Pendahuluan}

Angka kejadian alergi makanan terus meningkat di seluruh dunia dalam beberapa tahun terakhir ini. Alergi makanan itu dapat menyebabkan manifestasi pada gastrointestinal dan sistem organ yang lain. Reaksi ini terjadi karena reaksi silang antara alergen dan IgE sehingga muncul berbagai mediator inflamasi. ${ }^{1}$

Di Indonesia data prevalensi penyakit alergi makanan di Poliklinik Alergi-Imunologi Anak Rumah Sakit Cipto Mangunkusumo dari pasien anak yang menderita alergi, sekitar $2,4 \%$ berupa alergi susu sapi. Dilaporkan bahwa 8,5\% dari 284 anak asma disebabkan oleh alergen makanan dan sensitisasi terbanyak terjadi pada tahun pertama kehidupan dan diidentifikasi telur sebagai alergennya. Alergi makanan dibuktikan menjadi pemicu obstruksi bronkus pada $2-8,5 \%$ anak dengan asma. ${ }^{2}$

Limpa merupakan organ sangat penting yang berperan dalam sistem imun sehingga akan terpengaruh bila terjadi penurunan fungsi sistem imun. Limpa merupakan organ limfoid terbesar yang banyak mengandung sel fagositik dan ada hubungan erat antara darah yang beredar dan sel-sel fagositik sehingga limpa merupakan organ penting dalam menghadapi antigen yang menerobos masuk ke dalam sirkulasi. Limpa bereaksi segera terhadap antigen yang terbawa darah dan merupakan organ pembentuk antibodi yang penting. ${ }^{3}$ Aktivitas sistem imun pada limpa dapat diketahui dari ukuran diameter pulpa alba. Pembesaran diameter pulpa alba limpa terjadi akibat respons antigen yang masuk sehingga mengaktivasi sistem imun yang menyebabkan proliferasi sel-sel pada pulpa alba limpa. . $^{4-5}$

Respons imun tersebut dapat dipengaruhi oleh senyawa tertentu yang berasal dari tanaman. Berbagai macam keuntungan bahan alam dalam fungsinya untuk memodulasi fungsi sistem imun yang di antaranya menstimulasi, mensupresi, atau dapat menghapus beberapa respons imun tertentu. Salah satu tanaman buah yang sudah digunakan secara luas adalah semangka (Citrullus lanatus). Tumbuhan ini kaya akan flavonoid, alkaloid, saponin, glikosid, tanin, dan fenol. ${ }^{6}$ Senyawa flavonoid mampu bertindak sebagai senyawa imunosupresi dari gen proinflamasi yang mampu menurunkan reaksi inflamasi dan juga memengaruhi kadar mRNA. ${ }^{7}$ Mekanisme anti-inflamasi flavonoid melalui beberapa jalur, yaitu penghambatan aktivitas enzim COX atau lipooksigenase. Penghambatan jalur COX dan lipooksigenase ini secara langsung juga menghambat biosintesis eikosanoid dan leukotrien yang merupakan produk akhir jalur COX dan lipooksigenase. Flavonoid juga mampu menghambat akumulasi leukosit pada daerah inflamasi sehingga menurunkan adhesi leukosit ke endotel dan akibatnya terjadi penurunan respons inflamasi. Flavonoid juga dapat menghambat degranulasi neutrofil sehingga secara langsung mengurangi pelepasan asam arakidonat oleh neutrofil. Efek anti-inflamasi flavonoid didukung oleh aksinya sebagai antihistamin dengan cara flavonoid dapat menghambat pelepasan histamin dari sel mast. Flavonoid dapat menghambat enzim c-AMP fosfodiesterase sehingga kadar c-AMP dalam sel mast meningkat. Dengan demikian kalsium dicegah masuk ke dalam sel yang berarti juga mencegah pelepasan histamin. ${ }^{8}$

Tujuan penelitian ini adalah mengetahui perubahan diameter pulpa alba limpa mencit BALB/c yang diinduksi ovalbumin setelah pemberian ekstrak etanol buah Citrullus lanatus.

\section{Metode}

Penelitian ini merupakan eksperimental in vivo pada hewan uji dengan post-test only control group design. Variabel bebas pada penelitian ini adalah ekstrak etanol Citrullus lanatus dosis $175 \mathrm{mg} / \mathrm{kgBB} / \mathrm{hari} ; 350 \mathrm{mg} / \mathrm{kgBB} / \mathrm{hari}$; dan 700 $\mathrm{mg} / \mathrm{kgBB} /$ hari selama 28 hari berturut-turut. Variabel tergantung adalah diameter pulpa alba limpa mencit BALB/c. Variabel terkendali adalah mencit BALB/c jantan, umur 8 minggu, bobot \pm 20 gram yang dilakukan aklimatisasi selama 1 minggu, dipelihara dalam kandang, pencahayaan yang sama, diberi pakan standar BR 1, dan minum akuades.

Ekstrak didapatkan dari buah Citrullus lanatus matang yang dibuat menjadi simplisia, dimaserasi selama 7 hari menggunakan larutan penyari etanol $80 \%$ dan diuapkan sehingga akan didapatkan ekstrak kental. Ekstrak etanol diberikan per oral dengan alat bantu sonde pada mencit BALB/c selama 28 hari.

Hewan uji yang digunakan berjumlah 30 ekor dan dibagi menjadi 6 kelompok, masing-masing terdiri atas 5 ekor mencit. Keenam kelompok tersebut adalah kelompok kontrol normal (K$\mathrm{N}$ ), kelompok kontrol yang hanya disensitisasi dengan ovalbumin (K-OVA), kelompok kontrol yang disensitisasi dengan OVA dan diberi metilprednisolon 0,13 mg/hari (K-MP), dan tiga kelompok perlakuan dengan pemberian ekstrak etanol C. lanatus dosis $175 \mathrm{mg} / \mathrm{kgBB} /$ hari (K$\mathrm{P} 1$ ), dosis $350 \mathrm{mg} / \mathrm{kgBB} / \mathrm{hari}$ (K-P2), dosis 700 
$\mathrm{mg} / \mathrm{kgBB} /$ hari (K-P3). ${ }^{9}$

Mencit tersebut dibuat model alergi saluran pencernaan menggunakan disensitisasi secara intraperitoneal pada hari ke-15 dengan $0.15 \mathrm{~mL}$ OVA dalam $\mathrm{Al}(\mathrm{OH})_{3} /$ mencit dari $2,5 \mathrm{mg}$ OVA yang dilarutkan pada 7,75 mL aluminium hidroksida dan pada hari ke-22 dengan 0,15 mL OVA dalam akuades/mencit dari 2,5 mg OVA yang dilarutkan pada $10 \mathrm{~mL}$ akuades. Pada hari ke-23 hingga hari ke-28, mencit dipapar lagi per oral dengan 0,15 cc OVA dalam akuades yang dibuat dari 2,5 mg OVA dalam 2,5 mL akuades. Mencit dikorbankan 24 jam setelah pemberian OVA yang terakhir. ${ }^{10}$

Pembedahan mencit dilakukan pada hari ke-29. Mencit dikorbankan lalu diambil organ limpanya untuk dibuat menjadi preparat dengan metode blok parafin. Setelah itu, dilakukan pewarnaan preparat dengan hematoxysilin eosin. Pengamatan diameter pulpa alba limpa mencit menggunakan mikroskop cahaya dengan perbesaran $10 \times 10$ pada 10 lapang pandang. ${ }^{4-5}$
Pulpa alba yang diamati pada setiap preparat berjumlah 15 pulpa. Diameter didapatkan dari diameter maksimum pulpa yang dirata-rata dengan diameter maksimum tegak lurusnya.,11 Data penelitian ini berupa diameter pulpa alba limpa rata-rata yang didapatkan diuji normalitas distribusinya dengan menggunakan Kolmogorov-Smirnov. Data dianalisis dengan Kruskal-Wallis dan dilanjutkan dengan MannWhitney.

Seluruh perlakuan pada penelitian ini telah dikaji dan disetujui oleh Komite Etik Penelitian Fakultas Kedokteran dan Ilmu Kesehatan Universitas Muhammadiyah Yogyakarta dengan surat bernomor 025/EP-FKIK-UMY/I/2017.

\section{Hasil}

Penelitian ini dilakukan untuk membuktikan efek ekstrak etanol Citrullus lanatus terhadap
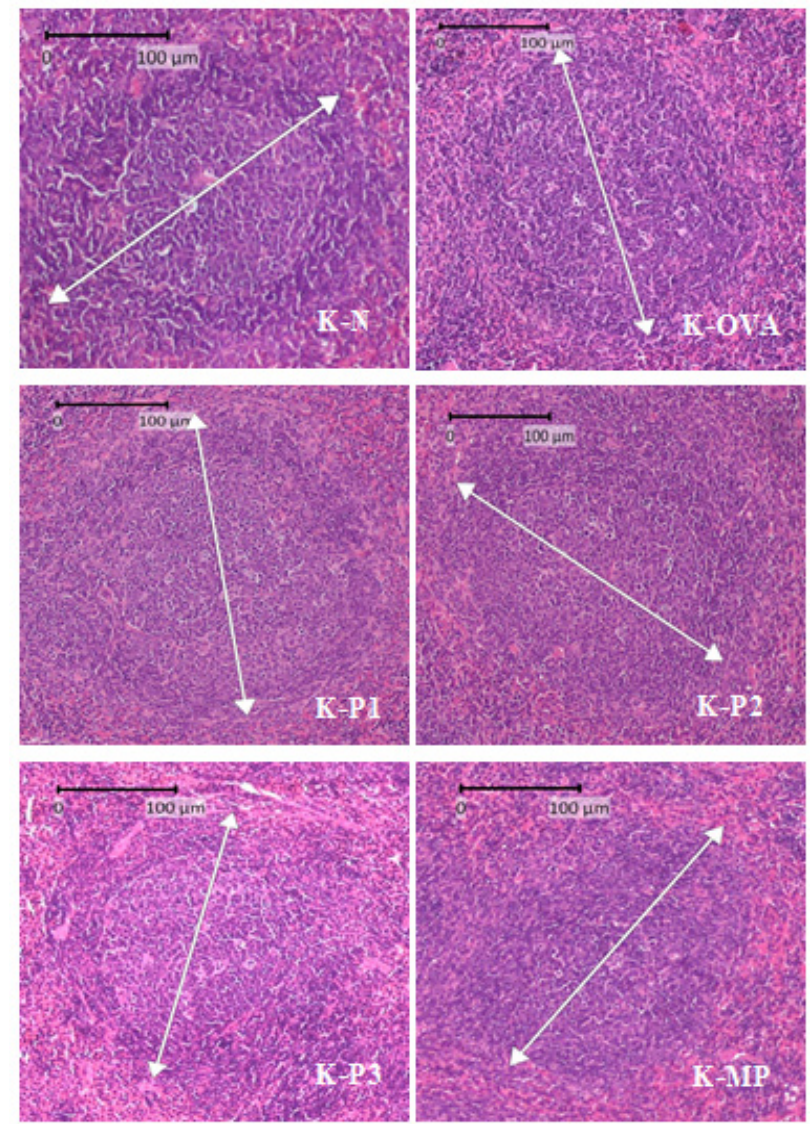

Gambar 1 Histologi Pulpa Alba Limpa Mencit BALB/c dengan Perwarnaan HE Perbesaran 10x pada Kelompok Normal (K-N), Kontrol Negatif (K-OVA), Kontrol Metilprednisolon (K-MP), dan Kelompok Perlakuan dengan Ekstrak Etanol C. lanatus Dosis 175 mg/kgBB (K-P1), 350 mg/kgBB (K-P2), 700 mg/kgBB Selama 28 Hari

Keterangan: $\leftrightarrow$ diameter pulpa alba limpa 
Tabel 1 Diameter Pulpa Alba Rata-rata Limpa Mencit $(x \pm$ SD) dengan Satuan $\mu \mathrm{m}$ Pada Kelompok Kontrol dan Kelompok Perlakuan Ekstrak Etanol Citrulus Lanasus L

\begin{tabular}{cc}
\hline Kelompok & $\begin{array}{c}\text { Diameter Pulpa Alba Limpa } \\
(\boldsymbol{\mu m})\end{array}$ \\
\hline K-N & $276,67 \pm 67,43^{\mathrm{a}}$ \\
K-OVA & $286,48 \pm 59,85^{\mathrm{b}}$ \\
K-P1 & $306,05 \pm 72,65^{\mathrm{bc}}$ \\
K-P2 & $318,57 \pm 80,86^{\mathrm{c}}$ \\
K-P3 & $258,63 \pm 51,92^{\mathrm{ad}}$ \\
K-MP & $256,05 \pm 45,01^{\mathrm{ad}}$ \\
\hline
\end{tabular}

Keterangan: SD: standar deviasi; a,b,c, : angka-angka yang diikuti oleh huruf yang sama tidak menunjukkan beda yang nyata antarkelompok

perubahan diameter pulpa alba limpa mencit BALB/c yang diinduksi ovalbumin. Gambaran histologi pulpa alba limpa mencit dapat dilihat pada Gambar 1. Diameter pulpa alba rata-rata limpa mencit BALB/c pada keenam kelompok dapat dilihat pada Tabel 1.

Kelompok perlakuan ekstrak etanol buah Citrullus lanatus dosis $350 \mathrm{mg} / \mathrm{kgBB}$ dan disentisisasi dengan OVA (K-P2) mempunyai diameter pulpa alba rata-rata yang paling tinggi, yaitu $318,57 \pm 80,86 \mu \mathrm{m}$, sedangkan kelompok kontrol MP dengan pemberian metilprednisolon per oral dosis 0,13 mg dan disentisisasi dengan OVA (K-MP) memiliki diameter pulpa alba ratarata paling rendah, yakni $256,05 \pm 45,01 \mu \mathrm{m}$. Pada kelompok perlakuan ekstrak etanol $C$. lanatus hanya kelompok ekstrak etanol buah $C$. lanatus dosis $700 \mathrm{mg} / \mathrm{kgBB}$ yang menunjukkan penurunan diameter pulpa alba rata-rata, yakni $258,63 \pm 51,92 \mu \mathrm{m}$. Kelompok ini memiliki ratarata lebih rendah dibanding dengan kelompok kontrol normal dan hampir sama dengan kelompok kontrol metilprednisolon.

Uji normalitas data dengan menggunakan Kolmogorov-Smirnov karena jumlah sampel lebih dari 50. Hasil uji normalitas menunjukkan bahwa K-P1 memiliki nilai $\mathrm{p}=0,007 \quad(\mathrm{p}<0,05)$ sehingga distribusi data pada kelompok ini tidak normal, sedangkan pada kelompok lain didapatkan nilai $p>0,05$ sehingga distribusi datanya normal. Pada uji homegenitas varians didapatkan hasil $\mathrm{p}<0,05$ yang menunjukkan bahwa data memiliki varians yang tidak sama. Data memiliki distribusi yang tidak normal dan varians yang berbeda maka tidak memenuhi syarat uji parametrik. Uji statistik yang dipilih adalah uji nonparametrik Kruskal-Wallis. Hasil uji Kruskal-Wallis didapatkan $\mathrm{p}=0,00(\mathrm{p}<0,05)$ berarti diameter pulpa alba limpa rata-rata pada keenam kelompok perlakuan memiliki

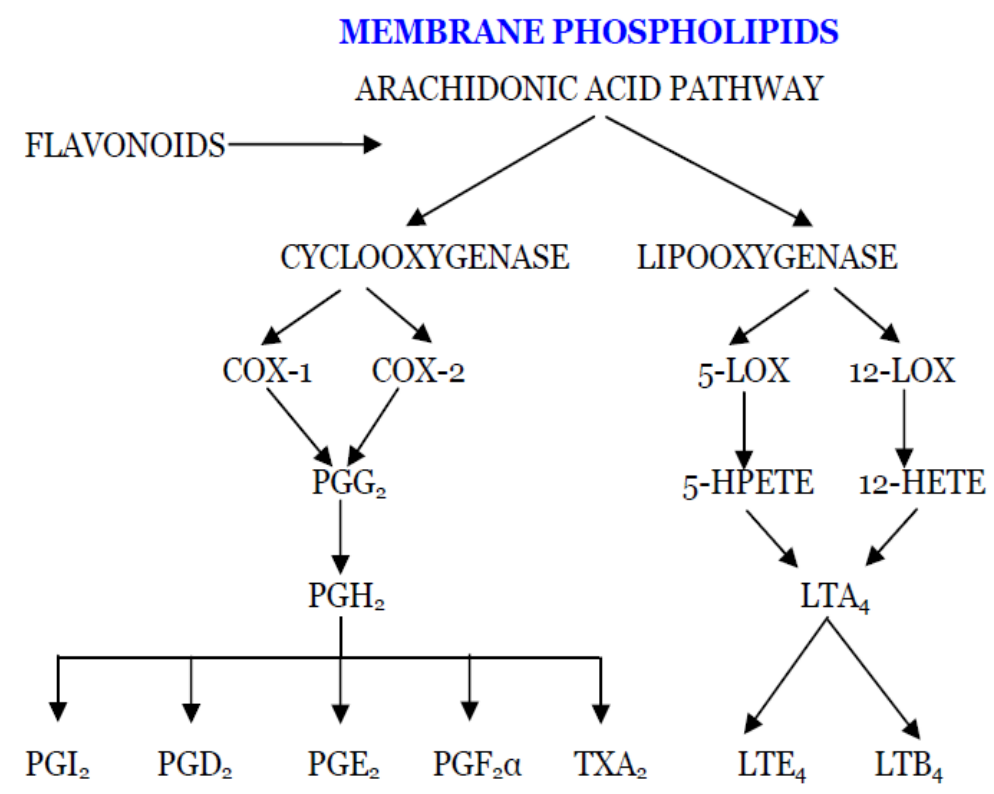

Gambar 2 Mekanisme Kerja Flavonoid pada Inflamasi ${ }^{17}$ 
perbedaan bermakna. Selanjutnya, dilakukan uji Mann-Whitney untuk mengetahui pada kelompok mana dari keenam kelompok tersebut yang memiliki perbedaan bermakna.

Hasil uji Mann-Whitney menunjukkan bahwa $\mathrm{K}-\mathrm{N}$ tidak memiliki perbedaan yang bermakna dengan K-P3 $(p=0,109)$ dan K-MP $(p=0,100)$ $(p>0,05)$, sedangkan K-OVA dengan K-P3 $(\mathrm{p}=0,004)$ dan K-MP $(\mathrm{p}=0,003)$ menunjukkan perbedaan bermakna $(\mathrm{p}<0,05)$. Hasil pengujian $\mathrm{K}-\mathrm{P} 3$ dengan K-MP menunjukkan nilai $\mathrm{p}=0,959$ $(p>0,05)$ sehingga kedua kelompok ini tidak memiliki perbedaan rata-rata diameter pulpa alba yang bermakna.

\section{Pembahasan}

Pada penelitian ini telah dilakukan uji efek imunosupresi ekstrak etanol Citrullus lanatus pada mencit BALB/c yang diinduksi oleh ovalbumin. Seluruh mencit, kecuali kelompok kontrol normal disensitisasi menggunakan OVA. Diameter pulpa alba pada kelompok kontrol negatif (K-OVA) lebih tinggi dibanding dengan rata-rata diameter pulpa alba rata-rata pada kelompok kontrol normal (K-N). OVA akan meningkatkan sel Th2 untuk menyekresikan berbagai macam interleukin (IL-4, IL-5, IL-9, dan IL-13) yang dapat meningkatkan tingkat inflamasi. $^{12}$ IL-4 merangsang sel B untuk membentuk IgE. IgE akan diikat oleh sel yang memiliki reseptor untuk IgE seperti sel mast, basofil, dan eosinofil. Apabila tubuh terpajan ulang oleh alergen maka sel mast itu akan mengalami degranulasi sehingga menyekresikan histamin, prostaglandin, dan leukotrien. ${ }^{13}$

Antigen asing dapat masuk ke dalam tubuh melalui lapisan epitel saluran pencernaan. Selsel dendritik di epitel akan mengikat antigen tersebut lalu masuk ke dalam saluran limfe untuk dibawa ke kelenjar getah bening regional agar diproses oleh limfosit T, sedangkan antigen yang tidak terikat sel dendritik di lapisan epitel akan bersirkulasi dalam aliran darah sehingga akan ditangkap oleh antigen presenting cells (APC) di dalam limpa untuk selanjutnya diproses oleh limfosit. ${ }^{14}$

Pada limpa, limfosit mengenal fragmen antigen non-self yang dipresentasikan makrofag, sel dendritik, dan fagosit. Presentasi fragmen antigen non-self diikuti oleh sekresi IL-12 dan IL18 yang akan menstimulasi sel T menghasilkan interferon- $\gamma$ (INF- $\gamma$ ) yang mengaktivasi sel NK (natural killer) dan $\mathrm{CD}^{+.13}$ Salah satu komponen limpa adalah pulpa putih (alba). Pulpa alba secara struktural menyerupai kelenjar getah bening. Pada pulpa alba terdapat zona sel limfosit $\mathrm{T}$ dan sel B (folikel) serta memungkinkan munculnya respons imun spesifik terhadap antigen yang melindungi tubuh dari infeksi bakteri, virus, dan fungi yang terbawa dalam darah. ${ }^{11}$

Respons imun limpa terhadap OVA adalah dengan meningkatkan aktivitas proliferasi selsel limfosit pada pulpa alba sehingga terjadi peningkatan ukuran diameter pulpa alba.

Peningkatan diameter pulpa alba pada K-OVA ini sesuai dengan penelitian yang dilakukan oleh Husain dan Makiyah $^{20}$ yang mengkaji peningkatan diameter pulpa alba limpa mencit akibat paparan gelombang telepon seluler. Hasil penelitian Makiyah $\mathrm{dkk}^{4}$ tentang peningkatan diameter pulpa alba akibat paparan ultraviolet $\mathrm{C}$ pada mencit. Dalam hal ini paparan gelombang telepon seluler dan sinar ultraviolet C dianggap sebagai antigen sehingga mampu mengakibatkan proliferasi sel-sel limfosit pada pulpa alba limpa mencit.

Kelompok kontrol metilprednisolon (K-MP) memperlihatkan diameter pulpa alba ratarata paling rendah. Mencit pada kelompok K-MP diberi metilprednisolon dosis $0,13 \mathrm{mg} /$ hari selama 28 hari. Metilprednisolon adalah obat golongan dari kortikosteroid. Manfaatnya antara lain mengatasi radang (anti-inflamasi), menekan sistem imun dalam proses alergi, mengatur metabolisme protein dan karbohidrat, memengaruhi kadar natrium dalam darah, dan lain-lain. Cara kerja obat tersebut sebagai agen anti-inflamasi dan imunosupresan adalah dengan menginduksi limfositopenia serta menghambat diferensiasi dan proliferasi limfosit. Obat ini akan mengganggu komunikasi intraselular antara leukosit dan produksi limfokin (IL-1, IL-2, dan TNF) sehingga fungsi makrofag akan terganggu. Namun, obat ini juga memiliki efek samping yang membahayakan tubuh jika digunakan dalam jangka waktu lama. Selama penelitian berlangsung terdapat dua mencit yang mati pada kelompok tersebut. Hal ini dapat disebabkan oleh efek samping metilprednisolon seperti atrofi otot, osteoporosis, moon face, buffalo hump, lemak ekstremitas berkurang, gangguan reabsorbsi $\mathrm{Na}^{+}$serta sekresi $\mathrm{K}^{+}$dan $\mathrm{H}^{+}$di ginjal, gangguan absorbsi $\mathrm{Ca}^{2+}$ di usus, serta gangguan neuropsikiatri. ${ }^{15}$

Pemberian ekstrak etanol Citrullus lanatus dosis $700 \mathrm{mg} / \mathrm{kgBB} /$ hari telah terbukti dapat menurunkan diameter pulpa alba limpa. Hasil uji statistik menunjukkan kelompok ekstrak etanol C. lanatus dosis $700 \mathrm{mg} / \mathrm{kgBB}$ memiliki rata-rata diameter yang tidak berbeda secara bermakna 
dengan kelompok kontrol normal dan kelompok kontrol metilprednisolon sebagai obat standar. Hal ini disebabkan karena ekstrak etanol $C$. lanatus dosis $700 \mathrm{mg} / \mathrm{kgBB}$ tersebut mengandung flavonoid dengan kadar yang optimal untuk menekan proliferasi limfosit dalam pulpa alba limpa sehingga mampu berperan sebagai agen imunosupresi secara optimal dan diameter pulpa alba limpa menurun setara dengan kelompok kontrol negatif dan kelompok kontrol metilprednisolon. Pada semangka terdapat kandungan flavonoid, alkaloid, saponin, glikosid, tanin, dan fenol. ${ }^{6}$ Ekstrak etanol C. lanatus dosis $700 \mathrm{mg} / \mathrm{kgBB}$ mampu berperan sebagai agen imunosupresi dengan baik setara dengan obat standar anti-inflamasi, yaitu metilprednisolon.

Salah satu senyawa penting yang terkandung pada semangka ini adalah flavonoid. Flavonoid adalah senyawa fenol yang dapat berperan sebagai agen anti-inflamasi. Hasil dari berbagai penelitian terdapat banyak mekanisme kerja senyawa flavonoid. Pertama, flavonoid dapat menghambat enzim yang mengatur respons inflamasi, terutama tirosin dan serin-treonin protein kinase yang berperan dalam tranduksi dan aktivasi sel dalam proses proliferasi sel $\mathrm{T}$, aktivasi limfosit B, serta produksi sitokin oleh monosit. Kedua, flavonoid dapat mengurangi produksi asam arakidonat dan prostaglandin, leukotrien, serta NO (nitrit oksida) dengan cara menghambat enzim fosfolipase A2, siklooksigenase (COX), lipooksigenase, dan nitrit oksida sintase (NOS). ${ }^{16}$

Penurunan diameter pulpa alba disebabkan efek anti-inflamasi flavonoid yang menghambat proliferasi sel limfosit. Hasil penelitian ini sesuai dengan penelitian oleh Gupta dkk. ${ }^{18}$ yang meneliti aktivitas anti-inflamasi dan juga imunosupresi kandungan flavonoid pada Santalum album, Butea frondosa, dan juga Emblica officinalis. Kandungan flavonoid tersebut terbukti menekan proliferasi serta menurunkan produksi nitrit oksida (NO) dan CD14 surface marker. Flavonoid mengatur penurunan aktivitas produksi NO pada sel mononuklear darah tepi (monosit) yang juga berhubungan langsung dengan sitokin proinflamasi yang berperan saat terjadi infeksi bakteri, virus, ataupun parasit.

Selain memiliki efek imunosupresi, flavonoid juga mempunyai efek imunostimulasi. Terlihat dari hasil diameter rata-rata kelompok ekstrak etanol C. lanatus dosis $175 \mathrm{mg} / \mathrm{kgBB}$ (K-P1) dan kelompok ekstrak etanol C. lanatus dosis 350 $\mathrm{mg} / \mathrm{kgBB}$ (K-P2) yang lebih tinggi dibanding dengan kelompok yang lain, termasuk K-OVA. Penelitian Gajalakshmi mengenai flavonoid pada tanaman Echinacea purpurea L. menunjukkan hasil bahwa kandungan senyawa ini dapat menstimulasi produksi NO dan pelepasan TNF- $\alpha$. Selain itu, flavonoid dapat meningkatkan jumlah dan aktivitas fagositosis sel makrofag. Peningkatan aktivitas makrofag disebabkan oleh peningkatan sekret sitokin yang dihasilkan oleh sel-sel imunokompeten, antara lain interleukin-1 dan interleukin-6. ${ }^{19}$ Sitokin-sitokin tersebut merupakan pengaktif sel makrofag sehingga aktivitas fagositosis makrofag dapat ditingkatkan. $^{20}$

Disimpulkan bahwa pemberian ekstrak etanol buah Citrullus lanatus dosis $700 \mathrm{mg} /$ $\mathrm{kgBB} /$ hari mampu menurunkan diameter pulpa alba limpa mencit BALB/c diinduksi ovalbumin sehingga berpotensi sebagai agen imunosupresi.

\section{Ucapan Terima Kasih}

Penulis mengucapkan terima kasih kepada Kemenristekdikti yang memberikan sebagian dana penelitian ini melalui PKM-Penelitian tahun 2016.

\section{Daftar Pustaka}

1. Valenta R, Hochwallner H, Linhart B, Pahr S. Food allergies: the basics. Gastroenterology. 2015;148(6):1120-31.

2. Baena-Cagnani CE, Teijiro A. Role of food allergy in asthma in childhood. Curr Opin Allergy Clin Immunol. 2001;1:145-9.

3. Bronte V, Pittet MJ. The Spleen in local and systemic regulation of immunity. Immunity. 2013;39(5):806-18.

4. Husain M, Makiyah SNN. Pengaruh pajanan gelombang telepon seluler terhadap struktur histologi limpa pada mencit (Mus musculus). J Kedokteran Yarsi. 2012;20(3):167-73.

5. Makiyah SNN, Iszamriach R, Nofariyandi, A. Paparan ultraviolet c meningkatkan diameter pulpa alba limpa dan indeks mitotik epidermis kulit mencit. Jurnal Kedokteran Brawijaya. 2014;28(1):17-21.

6. Deshmukh, CD, Jain A, Tambe MS. Phytochemical and pharmalogical profile of Citrullus lanatus (THUNB). Biolife. 2015; 3(2):483-8.

7. Durga M, Nathiya S, Devasena T. Multifarious actions of dietary flavonoids - implications in cancer and cataract. Int J Pharm Bio Sci 2014;5(2):404-16.

8. Hidayati NA, Listyawati S, Setyawan AD. 
Kandungan kimia dan uji antiinflamasi ekstrak etanol Lantana camara L. pada tikus putih (Rattus norvegicus L.) jantan. Bioteknologi. 2008;5(1):10-7.

9. Kantham, S. Influence of Carica papaya linn extracts on paracetamol and thioacetamide induced hepatic damage in rats. Internet J Pharmacol. 2009;9(1):1-5.

10. Makiyah SNN, Noor Z, Djati MS, Rifa'i M, Widodo. Ethanol extracts of tubers Dioscorea alata l. as antiallergic agents on mice balb/c induced with ovalbumin. Int J Pharma Bio Sci. 2014;5(3):214-20.

11. Anggarasari Y. Pengaruh pemaparan karbofuran terhadap gambaran diameter pulpa putih limpa mencit (Mus musculus). Veterinaria Medika. 2014;7(2):100-5.

12. Prasetyo D. Efek Pemaparan ovalbumin aerosol terhadap eosinofilia bronkus pada mencit balb/c. Nexus Medicus. Surakarta: Fakultas Kedokteran Universitas Sebelas Maret; 2007.

13. Baratawidjaja KG. Imunologi dasar. Edisi ke9. Jakarta: Balai Penerbit FKUI; 2009.

14. Novia A. Pengaruh pemberian ekstrak etanol umbi bawang dayak (Eleutherine bulbosa (Mill.) Urb.) secara oral pada mencit balb/c terhadap pencegahan penurunan jumlah sel yang terekspresi IFN- $\gamma$ dan peningkatan jumlah sel yang terekspresi CD14. J Biosains
Pascasarjana UNAIR. 2015;17(3):1-16.

15. Sudir J. Efek kortikosteroid terhadap metabolisme sel; dasar pertimbangan sebagai tujuan terapi pada kondisi akut maupun kronik. Dexa Media. 2007;20(2):7780.

16. García-Lafuente A1, Guillamón E, Villares A, Rostagno MA, Martínez JA. Flavonoids as anti-inflammatory agents: implications in cancer and cardiovascular disease. Inflamm Res. 2009;58(9):537-52.

17. Rang HP, Dale MM, Ritter JM, Flower RJ. Rand and dale's pharmacology. Edisi ke-7. London: Churchill Livingstone; 2007.

18. Gupta A., Khamkar PR, Chaphalkar SR. Inhibition of nitric oxide production and proinflammatory cytokines by aqueous extract of terminalia arjuna in human peripheral blood mononuclear cells. Int J Pharm Biol Sci Arch. 2014;2:29-33.

19. Gajalakshmi S, Vijayalakshmi S, Devirajeswari. Echinacea purpurea-a potent immunostimulant. J Pharm Sci Rev Res. 2012;14(2):47-52.

20. Makiyah A, Husin U, Sadeli R. Efek imunostimulasi ekstrak etanol umbi ilesiles terhadap aktivitas fagositosis sel makrofag pada tikus putih strain wistar yang diinokulasi Staphylococcus aureus. MKB. 2016;48(2):68-77. 